\title{
A GC-FID method for analysis of Lysinoalanine
}

2 Antonia Montilla, José Ángel Gómez-Ruiz, Agustín Olano, María Dolores del Castillo

3 Instituto de Fermentaciones Industriales, Consejo Superior de Investigaciones Científicas, Madrid, Spain.

5

6 Running title: GC analysis of LAL

7

8

9 Correspondence: Dr. Dolores del Castillo, Instituto de Fermentaciones Industriales, Consejo Superior

10 de Investigaciones Científicas, c/ Juan de la Cierva 3, 28006 Madrid, Spain

11 E-mail: delcastillo@ifi.csic.es

12 Fax: +34915644853

13 Abbreviations: LAL, lysinoalanine; BSA, bovine serum albumin; DPA, diaminopimelic acid;

14 MTBSTFA, $N$-methyl- $N$-(tert-butyldimethylsilyl)-trifluoracetamide; TEA, triethylamine; tBDMSi, $15 \mathrm{~N}$-(O)-tert-butyldimethylsilyl; FID, flame ionization detector

16 Keywords: Lysinoalanine, Gas-chromatography, $N(\mathrm{O})$-tert-butyldimethylsilyl derivatives. 


\section{ABSTRACT}

2 Lysinoalanine (LAL) is an unwanted by-product, which is formed during processing of protein 3 and protein-containing foods and feeds. A GC method for quantitative analysis of LAL under 4 conventional chromatographic conditions has been developed. The method was applied to the analysis 5 of pure standard substances, boiled eggs, commercial caseinates, fresh cheeses, fresh cheeses made 6 with milk supplemented with caseinate and fresh cheeses adulterated with caseinate after cheese 7 making process. Results demonstrated the reliability of the GC capillary chromatography for the 8 analysis of LAL in protein containing foods. Limits of detection and quantification of $50 \mathrm{ppm}$ and 152 9 ppm of LAL in protein, respectively, were achieved. Range of linearity, precision and accuracy of the 10 method, measured using diaminopimelic acid as internal standard, were satisfactory for quantification 11 purpose. The method might be also suitable for the quantitative analysis of others amino acids such as 12 lysine and arginine. Results also indicated the utility of this methodology for detecting protein quality 13 of egg products and caseinates as well as fresh cheese frauds. 


\section{Introduction}

Lysinoalanine [LAL, $N^{\varepsilon}$-(R, S-2-amino-2-carboxyethyl)-S-lysine] has been used as a marker of

3 thermal damage in foods. The mechanism of formation of this cross-linking amino acid takes place in

4 two main steps. The first step consisting in the formation of dehydroalanine residue from the $\beta$ -

5 elimination of cystine, serine or its derivatives ( $O$-phosphorylserine and $O$-glycosylserine) which is an

6 hydroxide ion-catalyzed reaction, followed by a second reaction involving the double bond of

7 dehydroalanine with a nucleophilic side chain of another amino acid, such as the $\varepsilon$-amino group of

8 lysine [1-2]. Formation of LAL along the protein chain may affect the nutritional and biological

9 properties of the treated proteins. Decreasing of essential amino acids and reducing of protein

10 digestibility, protein quality, mineral bioavailability and utilization, within other nutritional and

11 toxicological effects, are some of the negative consequences derived from LAL generation [1-2]. High

$12 \mathrm{pH}$, temperatures, and long exposure time make these transformations favorable. Thermal treatments at

13 basic $\mathrm{pH}$ are quite common in the food industry. Therefore, LAL may be found in widely consumed

14 foods such as, baby food, cereal products, chicken meat, egg products, gelatine, infant formulas, meat

15 products, caseinate, soy protein isolate, liquid milk, powdered milk, cheese among others [1, 3-16].

16 Significant concern arises with the detection of LAL in special foods, such as enteral nutrition

17 formulas, where the quality of the protein used in their formulation is particularly relevant because

18 these foods may be the sole nutrient source for patients during long periods of time [17]. In addition,

19 LAL has been considered a better quality marker than Maillard reaction products for assessing the

20 nutritional quality of proteins which are widely employed as ingredient in the food industry, for

21 instance caseins [9]. Therefore, strategies to minimize LAL formation during food processing and easy

22 methods for its routine determination need to be developed.

Various analytical procedures have been evaluated for determining LAL in protein and protein-

24 containing foods and feeds. Because LAL survives the acidic conditions of proteins hydrolysis 
1 commonly used for the analysis of amino acids [1], its determination can be performed by Ion-

2 Exchange Chromatography (amino acid analyzer) with colorimetric and fluorometry detection after an

3 acid protein digestion [18-19], GC analysis of n-butyl esters of $N(O)$-trifluoroacetyl derivatives [6, 20-

4 21], GC-MS analysis of diasteromeric $N(O, S)$-perfluoropropionyl isopropyl esters [22] or TLC and

5 HPLC analysis [14, 23-26]. Most of the data recently published related to LAL analysis in foods have

6 been acquired by the HPLC method proposed by Pellegrino et al. [9], based on derivatization with

7 FMOC-Cl, solid phase extraction, reverse phase chromatography and fluorescence detection. The

8 method is very sensitive $(0.5-1 \mu \mathrm{g} / \mathrm{g}$ protein equivalent to $\mathrm{ppm}$ in protein); however, the sample

9 preparation is complex and time consuming. The aim of this investigation was to find out a feasible

10 procedure to achieve an easy and specific determination of LAL in the range of concentration

11 commonly detected in protein containing foods. A GC-FID method has been developed to achieve this

12 purpose based on previous studies related to LAL analysis by GC [6, 20] and glycated and ascorbylated

13 proteins by GC-MS [27].

\section{Materials and methods}

\section{$15 \quad 2.1$ Chemicals}

All chemicals used were of analytical grade. LAL was obtained from Bachem AG (Bubendorf,

17 Switzerland). Bovine serum albumin (BSA), DL-2,6-diaminoheptanedioic acid also called 18 diaminopimelic acid (DPA) and $N$-methyl- $N$-(tert-butyldimethylsilyl)-trifluoracetamide (MTBSTFA) were from Sigma (St. Louis, USA). Hydrochloride acid was supplied by Panreac (Barcelona, Spain).

20 Triethylamine (TEA) and $N, N$-dimethylformamide (DMF) were from Merck (Darmstadt, Germany).

21 High purity water was produced in-house using a Milli-Q Synthesis A10 System (Millipore, Bellerica, 22 Mass., USA) and was used throughout. 


\section{$1 \quad 2.2$ Food samples}

\section{$2 \quad$ 2.2.1. Boiled eggs}

Grade A chicken eggs, medium size (53-63 g), laid by 7-8 days were obtained from a local farm and heated for $10,20,30,45$ and $60 \mathrm{~min}$. Starting temperature was $20-25^{\circ} \mathrm{C}$, after 10 min of heating 79 $82^{\circ} \mathrm{C}$ were achieved and water boiling point arrived by $14 \mathrm{~min}$. Shelling and separation of egg albumen from yolk were done carefully and manually. Samples were stored at $-20^{\circ} \mathrm{C}$ until analysis. Treatments were carried out in triplicate.

\subsubsection{Caseinates}

Sodium ( $n=2)$ and calcium caseinates $(n=3)$ were supplied by three European dairy companies.

\subsubsection{Fresh cheeses}

Raw cow milk from a local farmer was employed for cheese-making. Previous to the manufacture of the cheeses, the raw milk was pasteurized at $65^{\circ} \mathrm{C}$ for $30 \mathrm{~min}$.

Three different batches were prepared in triplicate. A first batch was prepared without calcium caseinate (A, control). The second batch (B) was based on fresh cheeses from pasteurized milk supplemented with calcium caseinate to reach a final concentration of $15 \mathrm{~g} / \mathrm{L}$ in milk. Briefly, after warming up the milk to $33^{\circ} \mathrm{C}$, a lactic starter was added and the milk stirred for 35 min to help the acid development. Subsequently, $0.025 \mathrm{~g} / \mathrm{L}$ calcium chloride were added and the milk stirred for another 5 min. Finally $0.05 \mathrm{~g} / \mathrm{L}$ of rennet were added. After $60 \mathrm{~min}$ of coagulation, the curd was cut and the whey drained from the cheese. This step was accompanied with heating the curd at $38^{\circ} \mathrm{C}$ for 20 min and gentle stirring followed by a first centrifugation step at $1700 \mathrm{~g}, 23^{\circ} \mathrm{C}$ for $60 \mathrm{~min}$. The purpose of these stages of the process was to increase the rate at which the curd contracts and squeezes out the whey making a hard curd. Once the curds had sufficiently hardened, salting for 30 min was performed. A second centrifugation step at described above was carried out. Then, cheeses were cut, stored in the fridge overnight, vacuum packed and frozen at $-20^{\circ} \mathrm{C}$ until analysis. 
1 A third batch of cheese samples consisting in fresh cheeses made as described above (A) to which 2.5,

25,10 and $15 \%$ of commercial calcium caseinate containing $605.0 \mathrm{ppm}$ of LAL in protein was added

$3(\mathrm{C} 1, \mathrm{C} 2, \mathrm{C} 3, \mathrm{C} 4)$ was also studied in the present paper. Adulterated cheeses were stored at $-20^{\circ} \mathrm{C}$ until 4 analysis.

\section{$5 \quad 2.3 \mathrm{GC}$ analysis}

\section{$6 \quad$ 2.3.1 Acid hydrolysis} thermally digested by $8 \mathrm{ml}$ of $6 \mathrm{M} \mathrm{HCl}$ in Pyrex glass bottles at $110^{\circ} \mathrm{C}$ for $23 \mathrm{~h}$. Prior incubation samples were degassed using a stream of helium for $2 \mathrm{~min}$. The hydrolyzed samples were cooled at room temperature and filtered through a Whatman 40 paper filter.

\section{$11 \quad$ 2.3.2 Derivatization}

Aliquots of filtrated hydrolyzates $(0.5 \mathrm{ml})$ were evaporated to dryness at $38-40^{\circ} \mathrm{C}$ with a vacuum rotary evaporator. After evaporation, derivatization of the dried samples was carried out according to the methods of Hasenkopf et al. [27] and Woo and Chang [28]. DMF (165 $\mu$ l) and TEA $(15 \mu \mathrm{l})$ were added to the dry sample and stirred for 1 min. Afterwards, $100 \mu 1$ of MTBSTFA, silylating reagent, were added and the reaction mixture was heated at $70^{\circ} \mathrm{C}$ for $60 \mathrm{~min}$. Derivatization reaction was stopped by cooling to room temperature and the samples containing $N-(O)$-tert-butyldimethylsilyl (tBDMSi) derivatives of the amino acids were injected onto the GC column.

\subsubsection{GC-FID analysis}

The chromatography was performed by using a Hewlett-Packard HP6890 (Waldbronn, Germany) gas chromatograph equipped with a flame ionization detector (FID). A CP-SIL 5CB commercial fused silica capillary column ( $100 \%$ bonded dimethylsiloxane, $25 \mathrm{~m}$ x $0.25 \mathrm{~mm}$ id, 0.25 $\mu \mathrm{m}$ film thickness) (Chrompack, Middelburg, The Netherlands) was used. The carrier gas (nitrogen) flow-rate was $1.2 \mathrm{ml} / \mathrm{min}$. The make up gas was also nitrogen at flow-rate of $20 \mathrm{ml} / \mathrm{min}$. Injector and 
1 derivatives were injected in split-less mode. The oven temperature was programmed from $100^{\circ} \mathrm{C}$, held

$21 \mathrm{~min}$, ramp to $250^{\circ} \mathrm{C}$ at $30^{\circ} \mathrm{C} / \mathrm{min}$, held for $42 \mathrm{~min}$, ramp to $300^{\circ} \mathrm{C}$ at $50^{\circ} \mathrm{C} / \mathrm{min}$ and held for $5 \mathrm{~min}$.

3 Data was acquired by means of HP ChemStations (Agilent Technologies Inc., Wilmington, USA).

4

The range of linearity of FID response was checked by employing a calibration curve of LAL.

The calibration curve was constructed by adding different amounts of LAL to a standard mixture containing known quantities of BSA and DPA to obtain final concentrations of LAL from 152 to 3800 ppm in protein. The mixtures were hydrolyzed, derivatized and the derivatives injected on to the column.

tBDMSi LAL derivative was quantified by internal standard method. All analyses were carried out in duplicate and the data were the mean values expressed as mg LAL / Kg protein (ppm in protein). Total nitrogen was determined by means of Kjeldahl method $[29,30]$ and the protein values were calculated using 6.25 and 6.38 as conversion factors for eggs and dairy products, respectively.

LAL peak identification was achieved by migration time, standard addition and mass spectrometry analysis.

\subsubsection{GC-MS analysis}

A HP-6890 chromatograph coupled to a MD 5973 quadrupole mass detector (Hewlett-Packard, Palo Alto, CA, USA) was employed. The separation of the tBDMSi amino acid derivatives was performed on a $30 \mathrm{~m} \times 0.25 \mathrm{~mm}$ id x $0.25 \mu \mathrm{m}$ film thickness, HP-5MS (bonded 5\% phenyl, 95\% dimethylpolysiloxane) fused silica capillary column from Agilent Technologies Inc. (Wilmington, USA). Helium was used as carrier gas. The oven temperature was programmed from $80^{\circ} \mathrm{C}$, held 1 min, ramp to $200^{\circ} \mathrm{C}$ at $50^{\circ} \mathrm{C} / \mathrm{min}$, ramp to $250^{\circ} \mathrm{C}$ at $10^{\circ} \mathrm{C} / \mathrm{min}$, held for $42 \mathrm{~min}$, ramp to $300^{\circ} \mathrm{C}$ at $50^{\circ} \mathrm{C} / \mathrm{min}$ and held for 5 min. Samples were injected in split-less mode. Mass spectrometer was operated in EI mode at $70 \mathrm{eV}$. Mass spectra were acquired using a G1701CA ChemStation Software (HewlettPackard, Palo Alto, CA, USA).

\subsubsection{Statistical analysis}


1 Statistical analysis (Microsoft Excel 2000) of data was performed by one factor analysis of

2 variance with a level of significance of $95 \%$.

\section{$4 \quad 3$ Results and discussion}

\section{$5 \quad 3.1$ GC setup}

Figure 1 shows the chromatogram of tBDMSi amino acid derivatives of hydrolyzed BSA

$7 \quad$ spiked with pure LAL to a final concentration of $3800 \mathrm{ppm}$ in protein, which is split up into two zones

8 to provide a better look of the GC-FID profile. tBDMSi-DPA eluted at 23.03 min while tBDMSi-LAL

9 showed a retention time of 48.61 min corresponding to a relative retention time of 2.11. tBDMSi-LAL peak was not detected in untreated/non spiked BSA hydrolyzates. Results indicated that DPA is a suitable internal standard for the determination of LAL by GC-FID agreeing with data previously described by Hasegawa et al. [6]. Purification of the sample was not necessary and stable baseline 13 during the analysis was obtained. well separated from the derivatives of the common twenty amino acids of proteins such as tBDMSiLysine (relative retention time of 0.36) and tBDMSi-Arginine (relative retention time of 0.43 ). Most of the 20 amino acids found in proteins eluted within 20 minutes of analysis with the exception of cystine, which showed a retention time of $47.2 \mathrm{~min}$ equivalent to a relative retention time of 2.05 . Since chromatographic interferences have not been observed simultaneous analysis of arginine, lysine and LAL might be carried out under the proposed conditions.

tBDMSi-LAL was also analyzed by GC-MS. For this compound, one peak appeared in the chromatogram corresponding to a derivatization product with four silyl groups. Chemical structure and mass spectrum of tBDMSi-LAL are shown in Figure 2. The most common MS fragments found in EI mass spectrum of the tBDMSi derivative of LAL agreed with those previously described by Hasenkopf et al. [27] for others tBDMSi derivatives of amino acids. The $\left[\mathrm{M}^{+}\right]$ion was not identified. Instead [M- 
$157]^{+}$ion, which corresponds to the LAL with four silyl groups and the loss of $\mathrm{C}\left(\mathrm{CH}_{3}\right)_{3}$ was detected.

2 Ion with $\mathrm{m} / \mathrm{z} 387$ [M-159-131-15] $]^{+}$due to a simultaneous loss of COOtBDMS, OtBDMS and $\mathrm{CH}_{3}$, can

3 also be observed in Figure 2 as the most prominent fragment.

Detection and quantification limits were determined as three and ten folds the $\mathrm{S} / \mathrm{N}$

5 (signal/noise) ratio near the retention time of LAL, respectively. Detection and quantification limits of

$650 \mathrm{ppm}$ in protein and $152 \mathrm{ppm}$ in protein, respectively were obtained. Sensitivity for the determination

7 was lower than that reported by HPLC ( 1 ppm in protein) [9] and similar to those reported using GC-

8 NPD (nitrogen-phosphorus detection) [20] and ion-exchange chromatography ( $\geq 100$ ppm in protein)

9 [31]. The results suggested that the method provides the necessary selectivity avoiding a previous clean

10 up step of the sample. In widely consumed foods such pasteurized, UHT and sterilized milks LAL

11 values ranged from 17 to 69,49 to 186 and 224 and $653 \mathrm{ppm}$ in protein have been measured [14].

12 Upper limits of $200 \pm 100$ and 1000 ppm of LAL in protein for dried and liquid products, respectively,

13 have been legally established in Germany for special foods like infant products [14, 32] and also

14 recommend by the European regulatory organization [33]. Moreover, a low LAL content in foodstuffs

$15(<500 \mathrm{ppm}$ in protein) has been recommended in order to obtain positive benefit from the nutritional point of view [34], amounts which are measurable by the proposed method. Most of the harmful effects associated to LAL have been caused by daily ingestion of doses higher than $500 \mathrm{ppm}$ in protein [1].

Figure 3 shows a LAL standard curve ranged from 152 to $3800 \mathrm{ppm}$ in protein. A linear relationship $(y=3.6624 x+0.0155)$ between the response measured as peak area and concentration of LAL over this range was observed. The regression coefficient of the curve was 0.9859 . One factor analysis of variance of the response factor of LAL demonstrated significant homogeneity of the variance between the samples over the range of concentration studied since a $F$-value of 0.7327 with $P=0.8235(P>0.05)$ was obtained. Data agreed with those reported by Hasegawa et al. [6]. The precision of the method was estimated by analysis of BSA sample spiked with 380 ppm of LAL in protein within the same day (repeatability, $n=3$ ) and in different days (intermediate precision, $n=4$ ), 
1 obtaining relative standard deviations of 5.23 and 7.75 , respectively. Recovery of the method was also

2 evaluated by adding known amounts of LAL to pure BSA, raw albumen and fresh cheese (A). Average

3 values of $94.0 \%, 90.2 \%$ and $91.1 \%$ of LAL were recovered from hydrolyzates of BSA, raw albumen

4 and fresh cheeses, respectively.

Although the GC analysis of tBDMSi-LAL has been previously proposed, this is the first time

6 that capillary columns commercially available are used. The use of commercial GC columns could

7 facilitate the development of standardized procedures. The method here reported offers significant

8 improvements with respect to previous methods based on GC analysis of tBDMSi-LAL in terms of

9 simplicity, time of analysis and resolution. In addition, it allows simultaneous quantitative

10 determination of LAL and the common twenty amino acids found in proteins, among them lysine,

11 which is an essential amino acid considered as a chemical indicator for control of protein nutritional

12 quality in processed foods.

\section{3.2. Analysis of LAL in food samples}

To study the applicability of the validated method the presence or formation of LAL in different

15 food matrices (boiled eggs, caseinates and fresh cheeses) was evaluated.

16

17

\subsubsection{Crosslinking during boiling of eggs}

Table 1 shows the concentration of LAL found in fresh and boiled albumen and yolk. No LAL was observed in raw samples. LAL content increased progressively as a function of the heating treatment time. Rate of LAL formation in boiled white was faster than that detected in the boiled yolk egg. Similar levels of LAL in both, albumen and yolk, have been found by Hasegawa et al. [6].

\subsubsection{LAL in commercial caseinates and experimental fresh cheeses}

LAL values up to $605.0 \mathrm{ppm}$ in protein were detected in commercial caseinates. Data agreed with those previously reported by others authors $[1,10]$. GC profile corresponding to calcium caseinate, which showed the highest LAL content within the samples under study, is presented in Figure 4A. 
Table 2 shows the LAL content of both fresh cheeses and fresh cheeses made from milk

2 supplemented with calcium caseinate. Chromatograms of both cheeses are shown in Figure 4B and 4C.

3 No LAL was detected in fresh cheeses (Figure 4B and Table 2). No LAL or quantities of this

4 compound lower than 69 ppm have been reported in pasteurized milk $[1,14]$. LAL is not a suitable

5 marker for milks but it is for caseins and caseinates [10]. In cheeses based on milk supplemented with

$615 \mathrm{~g} / \mathrm{L}$ of calcium caseinate (B), values from 140.2 to $207.6 \mathrm{ppm}$ of LAL in protein were detected

7 (Table 2). Differences in LAL contents might be due to a differential rate of caseinate absorption

8 during cheese making which is in agreement with protein data. Higher values of LAL corresponded to

9 higher protein contents (Table 2).

10 Adulteration of fresh cheeses with amounts of caseinates ranged from $2.5 \%$ to $15 \%$ (C) was

11 detected by employing the GC methodology here described. A good relationship between the expected

12 and the experimental LAL data was obtained. Calculated values for LAL in fresh cheeses adulterated

13 with $10 \%$ (167.1 ppm in protein) and $15 \%$ (208.8 ppm in protein) of caseinate agreed with those

14 expected (179.8 and $234.4 \mathrm{ppm}$ in protein, respectively) suggesting the feasibility of the method to

15 detect cheese adulterations with caseinates like Mozzarella substitutes $(1,9-10,16)$.

\section{Concluding remarks}

17 The proposed procedure allows the quantitative analysis of LAL by gas capillary 18 chromatography employing conventional conditions without complex and time-consuming preparation.

19 In addition, lysine, arginine and others amino acids may be analyzed employing the proposed 20 methodology. Results indicated the feasibility of this analytical tool for detecting protein quality of egg 21 products, caseinates and fresh cheese frauds.

\section{Acknowledgments}

This study was funded by the Spanish Ministry of Education and Science (project AGL200424 05031). 


\section{References}

2 [1] Friedman, M., Chemistry, biochemistry, nutrition, and microbiology of lysinoalanine, lanthionine, 3 and histidinoalanine in food and others proteins. J. Agric. Food Chem. 1999, 47, 1295-1349.

4 [2] Boschin, G., Scaglioni, L., Arnoldi, A., Optimization of the synthesis of the cross-linked amino acid

5 ornithinoalanine and nuclear magnetic resonance characterization of lysinoalanine and ornitinoalanine.

6 J. Agric. Food Chem. 1999, 47, 939-944.

7 [3] Maga, J.A., Lysinoalanine in foods. J. Agric. Food Chem. 1984, 32, 955-964.

8 [4] Friedman, M., Levin, C.E., Noma, A.T., Factors governing lysinoalanine formation in soy proteins. 9 J. Food Sci. 1984, 49, 1282-1288.

10 [5] Büser, W., Erbersdobler, H.F., Carboxymethyllysine, a new compound of heat damage in milk 11 products. Milchwissenschaft-Milk Sci. Int. 1986, 12, 780 and 785.

12 [6] Hasegawa, K., Mukai, K., Gotoh, M., Honjo, S., Matoba, T., Determination of lysinoalanine 13 content in commercial foods by gas chromatography-selected ion monitoring. Agric. Biol. Chem. 1987, $14 \quad 51,2889-2894$.

15 [7] Dehnmuller, B., Muller, B., Erbersdobler, H.F. Studies on protein damage in UHT milk. 16 Milchwissenschaft-Milk Sci. Int. 1991, 46, 431-434.

17 [8] Davies, R. L., D-Lysine, alloisoleucine and lysinoalanine in supplementary proteins with different 18 lysine availabilities. J. Sci. Food Agric. 1993, 61, 151-154.

19 [9] Pellegrino, L., Resmini, P., de Noni, I., Masotti, F., Sensitive determination of lysinoalanine for 20 distinguishing natural from imitation Mozzarella cheese. J. Dairy Sci. 1996, 79, 725-734. 
1 [10] Resmini, P., Pellegrino, L., de Noni, I., Lysinoalanine, a molecular marker for characterising 2 natural Mozzarella cheese. Food Australia 1997, 49, 115-118.

3 [11] Rodriguez-Estrada, M.T., Penazzi, G., Caboni, M.F., Bertacco, G., Lercker, G., Effect of different 4 cooking methods on some lipid and protein components of hamburgers. Meat Sci. 1997, 45, 365-375.

5 [12] Chang, H.M., Tsai, C.F., Li, C.F., Changes of amino acid composition and lysinoalanine formation 6 in alkali-pickled duck eggs. J. Agric. Food Chem. 1999, 47, 1495-1500.

7 [13] Chang, H.M., Tsai, C.F., Li, C.F., Inhibition of lysinoalanine formation in alkali-pickled duck egg 8 (Pidan). Food Res. Int. 1999, 32, 559-563.

9 [14] Faist, V., Drusch, S., Kiesner, C., Elmadfa, I., Erbersdobler, H.F., Determination of lysinoalanine 10 in foods containing milk protein by high-performance chromatography after derivatisation with dansyl 11 chloride. Int. Dairy J. 2000, 10, 339-346.

12 [15] D’Agostina, A., Boschin, G., Rinaldi, A., Arnoldi, A., Updating on the lysinoalanine content of 13 commercial infant formulae and biscuits products. Food Chem. 2003, 80, 483-488.

14 [16] Resmini, P., Pellegrino, L., Cattaneo, S., Furosine and other heat-treatment indicators for detecting 15 fraud in milk and milk products. Ital. J. Food Sci. 2003, 15, 473-484.

16 [17] Boschin, G., D’Agostina, A., Rinaldi, A., Arnoldi, A., Lysinoalanine content of formulas for 17 enteral nutrition. J. Dairy Sci. 2003, 86, 2283-2287.

18 [18] Friedman, M., Cuq, J.L., Chemistry, analysis, nutritional value, and toxicology of tryptophan in 19 food. J. Agric. Food Chem. 1988, 36, 1079-1093.

20 [19] Fritsch, R.J., Klostermeyer, H., Improved method for determination of lysinoalanine in food. $Z$. 21 Lebensm. Unters. Forsch. 1981, 172, 101-106. 
1 [20] Büser, W., Erbersdobler, H.F., Determination of lysinoalanine as heptafluorobutyryl isobutyl ester

2 derivative by gas-liquid chromatography. J. Chromatogr. 1984, 303, 234-237.

3 [21] Hasegawa, K., Iwata, S., Gas chromatography-mass spectrometry of lysinoalanine and the related 4 crosslinked amino acids in alkali-treated food proteins. Agric. Biol. Chem. 1982, 46, 2513-2520.

5 [22] Liardon, R., Friedman M., Philippossian, G., Racemization kinetics of free and protein-bound 6 lysinoalanine (LAL) in strong acid media. Isomeric composition of bound LAL in processed proteins. 7 J. Agric. Food Chem. 1991, 39, 531-537.

8 [23] Aymard, C., Cuq, J.L., Cheftel, J.C., Formation of lysinoalanine and lanthionine in various food 9 proteins heated at neutral or alkaline pH. Food Chem.1978, 3, 1-5.

10 [24] Badoud, R., Pratz, G., Simple and rapid quantitative determination of lysioalanine and protein 11 hydrolysate amino acids by high-performance liquid chromatography after derivatization with dansyl 12 chloride. Chromatographia 1984, 155- 164.

13 [25] Antila, P., Pullinen, E., Antila, V., The formation and determination of lysinoalanine in foods 14 containing milk protein. Meijeritiet. Aikak. 1987, 45, 1-18.

15 [26] Moret, S., Cherubin, S., Rodriguez-Estrada, M.T., Lercker, G., Determination of lysinoalanine by 16 high performance liquid chromatography. J. High Res. Chrom., 1994, 17, 827-830.

17 [27] Hasenkopf, K., Rönner, B., Hiller, H., Pischetsrieder, M., Analysis of glycated and ascorbylated 18 proteins by gas chromatography-mass spectrometry. J. Agric. Food Chem. 2002, 50, 5697-5703.

19 [28] Woo, K.L., Chang, D.K., Determination of 22 protein amino acids as N(O)-tert-butyldimethylsilyl 20 derivatives by gas chromatography. J. Chromatogr. 1993, 638, 97-107.

21 [29] AOAC Official methods of Analysis, $15^{\text {th }}$ Ed. (1990). Nitrogen in eggs. No. 925.31, page 854. 
1 [30] International Dairy Federation. IDF Norma nº 24 (1964).

2 [31] Erbersdobler, H.F., Holstein, B., Lainer, E., Simultaneous determination of lysine, lysinoalanine,

3 furosine, and pyridosine in food and feed. Z. Lebensm. Unters. Forsch. 1979, 168, 6-8.

4 [32] Bundengesundheitsamt (1990), Bundegesetzblatt 29, 166.

5 [33] 2002/150/EC: Commission Decision of 15 February 2002 authorising the placing on the market of 6 coagulated potato proteins and hydrolysates thereof as novel food ingredients under Regulation (EC)

7 No 258/97 of the European Parliament and of the Council (notified under document number C(2002) 8 506). Official Journal $L \quad 050 \quad$, 21/02/2002, $\quad 92-93 . \quad$ http://eur9 lex.europa.eu/LexUriServ/LexUriServ.do?uri=CELEX:32002D0150:EN:NOT.

10 [34] ANNUAL REPORT 2004. ALP Liebefeld - Posieux. Agroscope Liebefeld-Posieux (ALP). Swiss 11 Federal Research Station for Animal Production. and Dairy Products.

12 www.alp.admin.ch/en/publikationen/docs/annual_report_2004.pdf, page 21. 


\section{Figure legends}

2

3 Figure 1. GC chromatogram of tBDMSi amino acid derivatives of hydrolyzed BSA spiked with pure

4 LAL. GC profile is split up into two zones as follows: Panel A shows those peaks corresponding to the

5 tBDMSi derivatives DPA, DL-2,6-diaminoheptanedioic acid (internal standard) and LAL,

6 lysinoalanine while in Panel B can be observed the derivatives of arginine, lysine and DPA.

7 Figure 2. Chemical structure and mass spectrum of tBDMSi derivative of pure LAL obtained by 8 electron impact ionization GC-MS.

9 Figure 3. Relationship between response (Areas) ratio and weight ratio of tBDMSi-LAL and tBDMSi10 DPA obtained by capillary GC-FID analysis.

11 Figure 4. GC-FID profiles of tBDMSi amino acid derivatives of hydrolyzed commercial calcium

12 caseinate (A), fresh cheese (B) and fresh cheese made from milk containing $15 \mathrm{~g} / \mathrm{L}$ of calcium 13 caseinate $(\mathrm{C})$. 
1 Table 1. LAL contents formed by boiling eggs. Results are expressed as mean \pm S.D. ( $n=3$ ).

\begin{tabular}{|c|c|c|}
\hline \multirow{2}{*}{ Heating conditions } & Egg albumen & LAL content (ppm in protein) \\
\cline { 2 - 3 } & N.D & N.D \\
\hline Raw & traces & N.D \\
\hline $79-82^{\circ} \mathrm{C}, 10$ min & & N.D \\
\hline Heating 20 min $(6$ min boiling) & $153.3 \pm 26.6$ & traces \\
\hline Heating 30 min (16 min boiling) & & traces \\
\hline Heating 45 min (31 min boiling) & $622.4 \pm 58.7$ & $154.4 \pm 28.5$ \\
\hline Heating 60 min (46 min boiling) & $677.0 \pm 63.4$ & \\
\hline N.D.= no detected & & \\
\hline
\end{tabular}


1 Table 2. Protein and LAL contents of experimental fresh cheeses. A, control fresh cheeses, B, fresh

2 cheeses made from milk supplemented with $15 \mathrm{~g} / \mathrm{L}$ of caseinate. Results are expressed as mean \pm S.D $3 \quad(n=3)$.

\begin{tabular}{|l|c|c|}
\hline Sample & LAL (ppm in protein) & Protein (g/100 g of product) \\
\hline A1 & 0 & 20.9 \\
\hline A2 & 0 & 21.6 \\
\hline A3 & 0 & 21.1 \\
\hline B1 & $158.9 \pm 26.5$ & 22.3 \\
\hline B2 & $207.6 \pm 18.6$ & 23.1 \\
\hline B3 & $140.2 \pm 9.5$ & 21.3 \\
\hline
\end{tabular}


1 Figure 1.
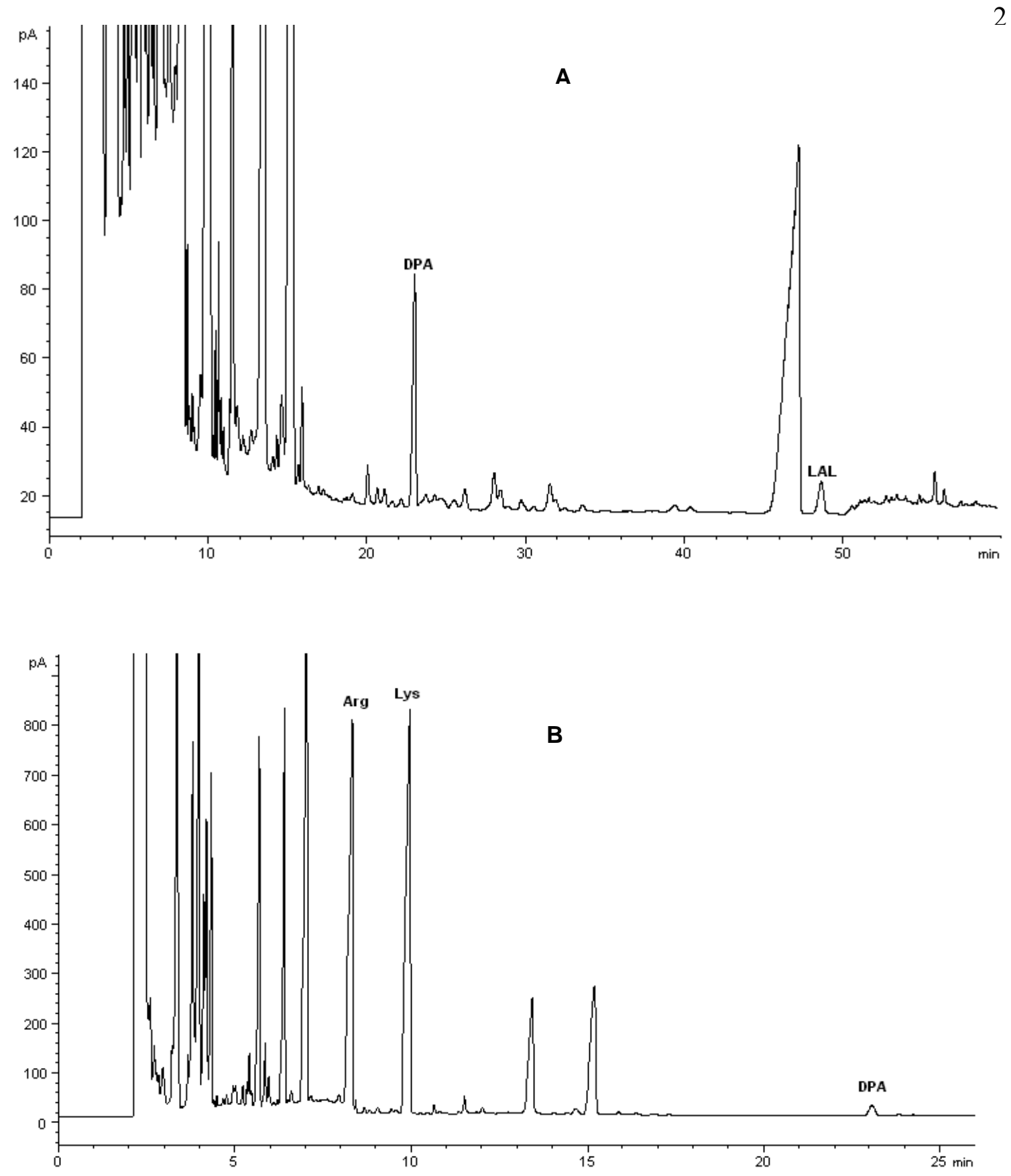
$1 \quad$ Figure 2

2
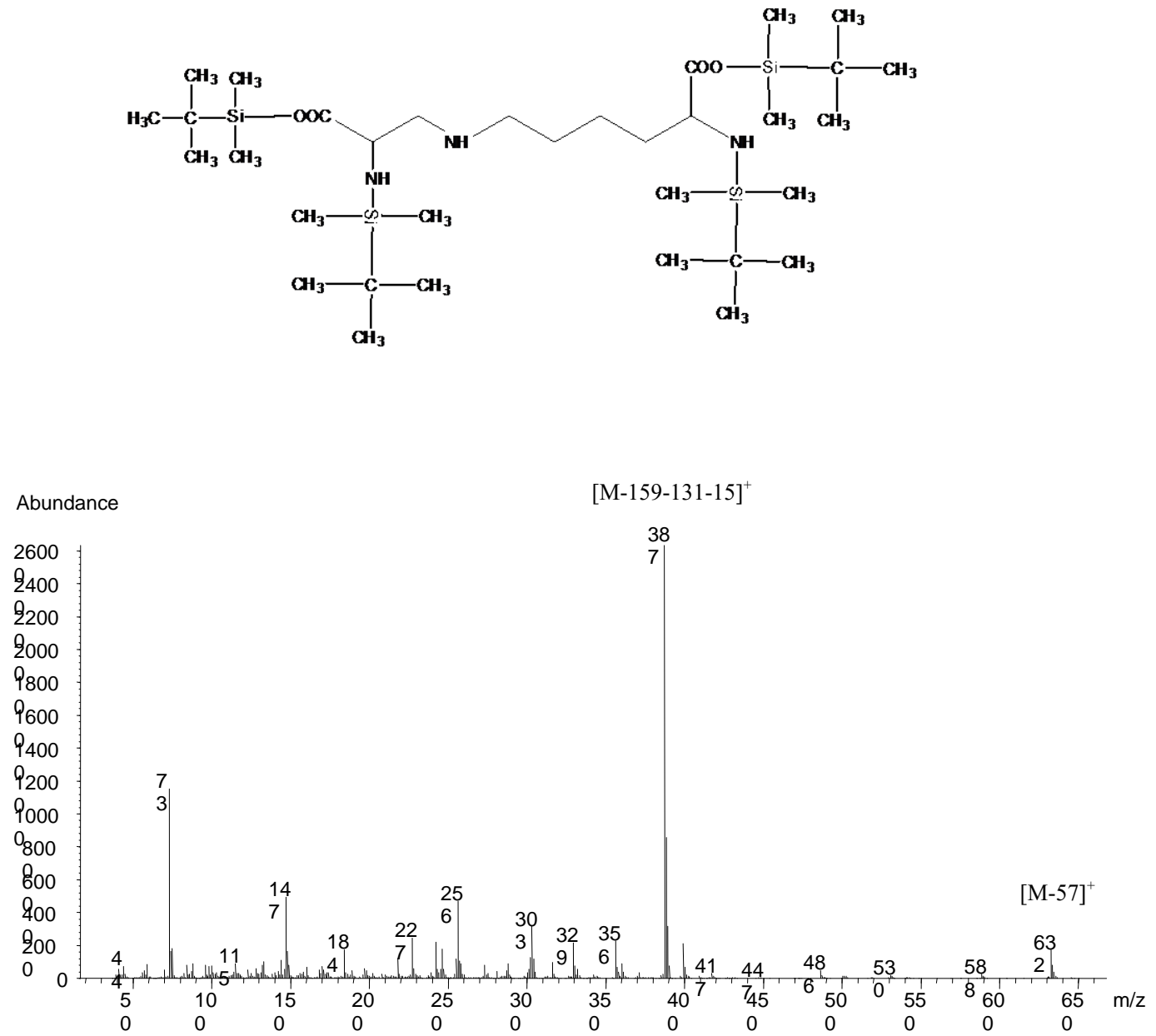
1 Figure 3.

2

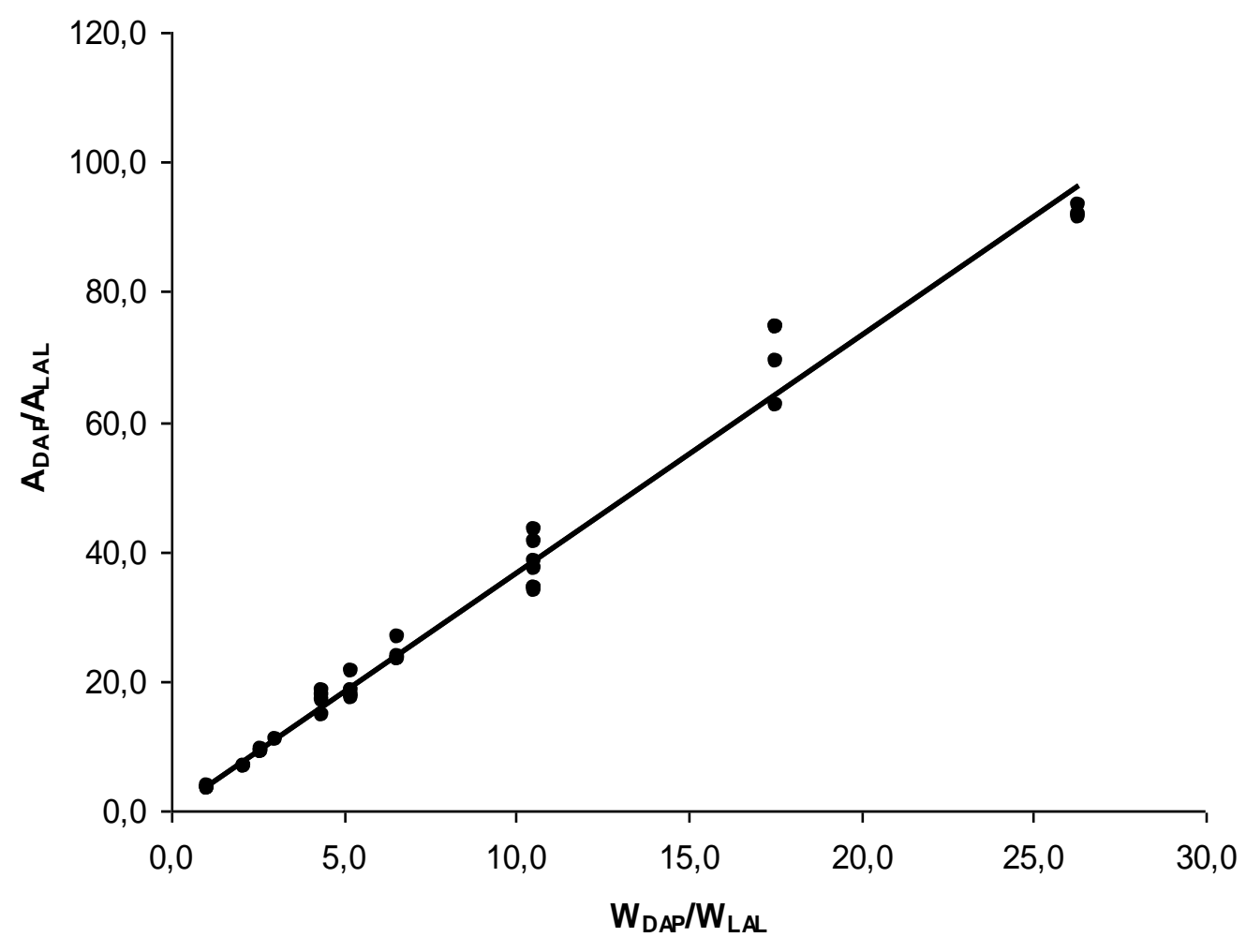


$1 \quad$ Figure 4

2
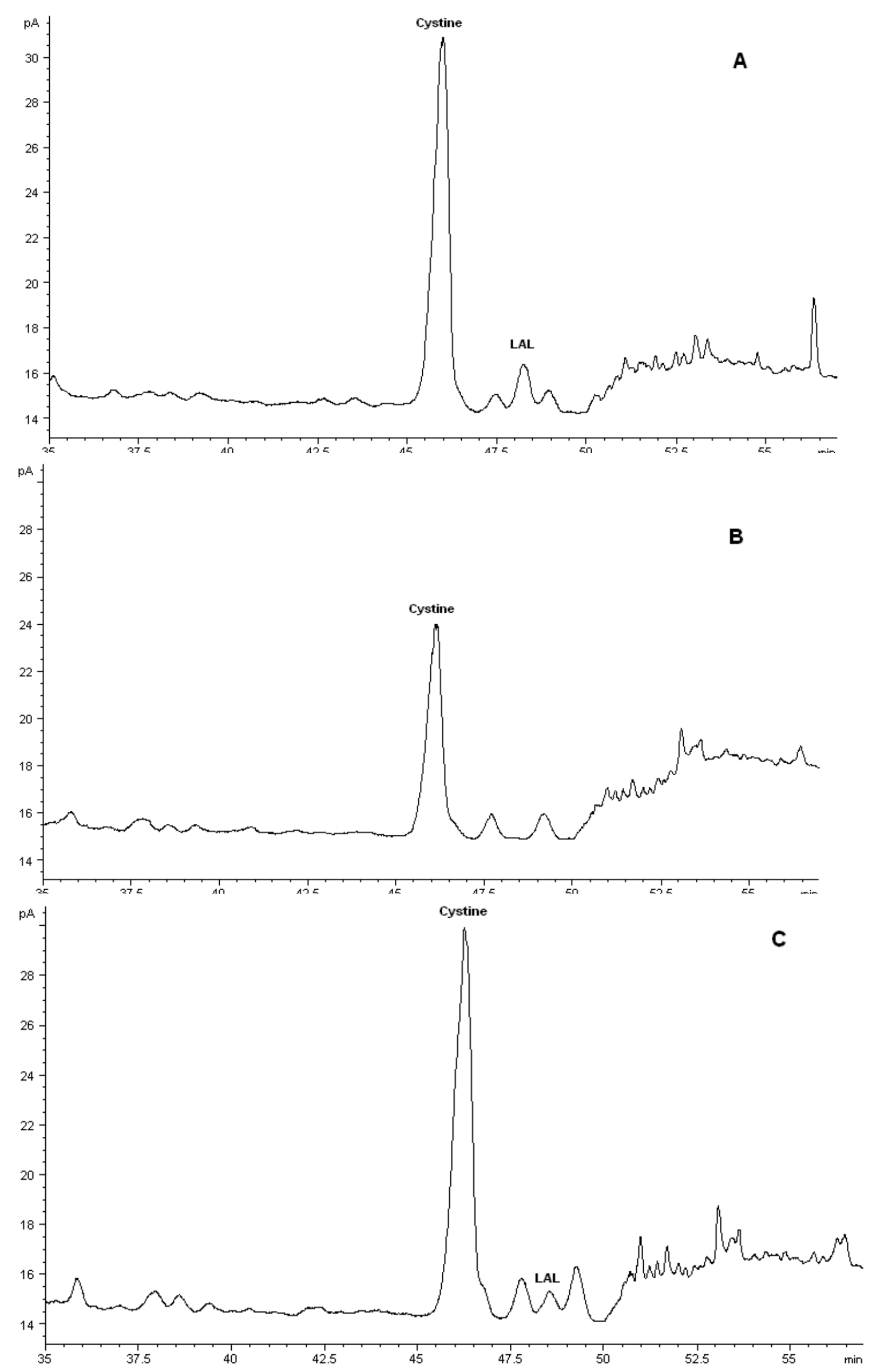